\title{
Human-induced physical disturbances and their indicators on coral reef habitats: A multi-scale approach
}

\author{
Pascale Chabanet ${ }^{1,2, a}$, Mehdi Adjeroud ${ }^{3}$, Serge Andréfouët ${ }^{1}$, Yves-Marie Bozec ${ }^{4}$, Jocelyne Ferraris ${ }^{1,3}$, \\ Jose-Antonio Garcìa-Charton ${ }^{5}$ and Muriel Schrimm ${ }^{3}$ \\ 1 IRD, UR CoRéUs, BP A5, 98848 Nouméa Cedex, Nouvelle-Calédonie, France \\ 2 Université de La Réunion, ECOMAR, BP 7151, 97715 St-Denis Cedex 9, La Réunion, France \\ 3 EPHE, Université de Perpignan, Laboratoire de Biologie marine et Malacologie, UMR 8046 CNRS, 66860 Perpignan Cedex, France \\ 4 IRD, UR-CoRéUs, Agrocampus Rennes, Département halieutique UPR MESH CS 84215, 35042 Rennes Cedex, France \\ 5 Dep. Ecología e Hidrología, Universidad de Murcia, Campus de Espinardo, 30100 Murcia, Spain
}

Received 22 June 2004; Accepted 27 June 2005

\begin{abstract}
This article aims to review 1) the major and most frequent human-induced physical disturbances and their consequences on coral reef habitats using a multi-scale approach, and 2) the scale-related indicators and conceptual aspects used to detect and measure the effects of these physical impacts. By physical disturbances, we mean direct perturbations that lead to the destruction/erosion of the carbonate framework. Human-induced direct physical disturbances are numerous from coastal development, tourism, harvesting, accidents and nuclear/weapon testing. Since methods for monitoring and measuring indicators are generally scale-implicit, coral reefs are first presented according to different ecological-spatial scales of organization, from colony to region (colony, reefscape, reef zone, whole reef, island and region). In this way, it is easier to link a couple \{habitat, disturbance\} to their potential indicators and to the descriptors they target. Three classes of descriptors, related to the response of the living component of coral reef ecosystem, are considered here: stony coral, reef fishes and the human uses. A synthesis of the different options for coral habitat assessments is proposed. We sort them according to their objectives (monitor, initial status or improvement of knowledge), their specificities (identification or not of a specific disturbances) and their scale of investigation (small, mesoor large scales). Usually, the majority of the indicators of human-induced disturbances are non-specific. They reveal that something is happening but not the actual causality and can only detect differences across time or space. A major weakness lies in the difficulty in deconvoluting the signals from a conjunction of stressors occurring at different scales. As such, a hierarchical concept of disturbances in coral reefs would be the next logical step to enhance our capabilities in monitoring and forecasting coral reefs status.
\end{abstract}

Key words: Coral reef / Physical disturbances / Habitat / Human-induced disturbances / Indicator

Résumé - Indicateurs des perturbations physiques et anthropiques de l'habitat corallien : une approche multi spatiale. Cet article a pour but d'examiner à travers une approche multi-spatiale 1) les principales et les plus fréquentes perturbations physiques sur l'habitat corallien et leurs conséquences, 2) les indicateurs de ces perturbations et les aspects conceptuels utilisés pour détecter et mesurer les effets de ces impacts. Seules, les dégradations physiques ayant un impact direct sur la destruction et l'érosion de la trame carbonatée du récif corallien sont considérées. Ce type d'impact, fréquent en milieu corallien, peut être généré par l'urbanisation du littoral, les activités touristiques (plongée sous-marine), la récolte d'organismes (piétinement, pêche à la dynamite), les essais nucléaires ou des accidents (échouage de navires). Les méthodes d'échantillonnage et les indicateurs utilisés pour le suivi des récifs étant reliés à l'échelle d'observation, les récifs coralliens sont abordés dans un premier temps en fonction de ces différentes échelles spatiales (colonie, paysage, partie du récif, récif en entier, île, région). De cette manière, il est plus facile de relier le tandem \{habitat, perturbation \} aux potentiels indicateurs et descripteurs ciblés. Trois classes de descripteurs reliées à la composante vivante de l'écosystème récifal sont considérées : les coraux constructeurs de récif, les poissons récifaux (Chaetodontidae) et l'homme à travers l'utilisation qu'il fait de l'écosystème. Une synthèse des différentes options pour évaluer l'état du récif corallien est proposée. Elles ont été sélectionnées en fonction des objectifs (suivi, état initial ou amélioration des connaissances), de leurs spécificités (identificateur ou non de la perturbation) et l'échelle d'investigation (petite, moyenne ou large). La majorité des indicateurs d'une perturbation anthropique n'est pas spécifique à un type de perturbation. Ils révèlent que quelque chose s'est passé, mais pas spécifiquement la cause actuelle de la perturbation; ils ne peuvent donc que détecter des différences au cours du temps ou de l'espace. Un des obstacles pour détecter spécifiquement une perturbation réside dans la difficulté de dissocier les signaux d'un ensemble de stress qui se répercutent à différentes échelles spatiales. Ainsi, une approche conceptuelle hiérarchique de perturbations en milieu corallien serait la prochaine étape à franchir pour améliorer nos connaissances afin de mieux suivre l'état des récifs coralliens et anticiper leurs dégradations.

a Corresponding author: chabanet@noumea.ird.nc 


\section{Introduction}

Coral reefs are characterized by their high species diversity and high gross productivity, among the highest of Earth's marine or terrestrial ecosystems (Connell 1978; Ray 1988). Coral reefs, frequently associated with seagrass beds and mangrove forests on tropical shorelines, supply vast numbers of people with goods and services such as seafood, recreational possibilities, and coastal protection providing significant aesthetic, cultural and economical benefits for many tropical countries (Done et al. 1996; Constanza et al. 1997; Berg et al. 1998).

Scleractinians (stony corals) are the main contributor of the reef framework since coral polyps secrete a carbonate skeleton at an average of $5 \mathrm{~kg}$ calcium carbonate per square meter (Kinsey 1985). The high calcification rates of these organisms are possible due to a symbiotic association with microscopic unicellular algae, the zooxanthellae that facilitate the growth and secretion of the calcium carbonate skeleton (Goreau 1959; Smith 1985; Gattuso et al. 1993, 1999). Crustose coralline algae, foraminifera and molluscs may also contribute significantly to the carbonate budget of a reef, which itself results from the accretion of the carbonate material at a geological scale. However, various agents balance continuously the calcification process through chemical, physical or biological erosion. As a result of a variety of environmental forcing and the duality between coral growth and carbonate dissolution/destruction, reefs provide a variety of three-dimensional complex habitats and niches for a variety of fish, molluscs, crustaceans and other reef-dwelling animals. The diversity of niches and habitats partially explain the diversity and structure of living community that exist on many coral reefs worldwide (Veron 1986; Done 1992).

Usually, ecologists consider as disturbances the factors that prevent calcification or enhance destruction/erosion of the carbonate framework. These disturbances play an important role in shaping continuously coral reef communities and their architecture (Connell 1978; Grigg 1983; Brown and Howard 1985; Hughes 1989; Grigg and Dollar 1990; Done 1992; Connell et al. 1997; Hughes and Connell 1999). Disturbances can be natural (e.g., ingestion by parrotfish of large amounts of coral rock, Bruggeman 1994; Peyrot-Claussade et al. 1995; sponges and echinoids grazing, Hutchings 1986) or induced by human activities.

Man-induced physical disturbances are numerous, including over-harvesting of reef organisms (Grigg 1984; Wells and Alcala 1987), coral mining (White 1987; Brown and Dunne 1988), destructive fishing methods (Carpenter and Alcala 1977; Alcala and Gomezn 1987; Gomez et al. 1987; McManus et al. 1997; Salvat et al. 2002; Erdmann 2000; Jackson et al. 2001; Fox et al. 2005) or uncontrolled land reclamation for tourism and coastal development (Tilmant 1987; Allison 1996; Hawkins and Roberts 1997; Guzman et al. 2003). The effects of these disturbances can be detected at different scales. These disturbances have direct consequences on stony corals ranging from colony to reef zone. With the expansion of human population on coastlines, and deforestation or intensive agriculture on the upstream watersheds, the increase in nutrient delivery (Marszaleck 1981a; Bell 1992; Naim et al. 2000), sediment and pollutant loads (Pastorok and Bilyard 1985) can have significant consequences at whole reef scale or even regional scale. Finally, activities occurring very far from the reefs may have consequences at a global scale. Indeed, greenhouse warming and global change are the usual suspects to explain more frequent occurrences of coral bleaching events, and may potentially increase hurricane frequencies and strengths (Knutson et al. 1998; Hoegh-Guldberg 1999; Kleypas et al. 2001). Human impacts and increased fragmentation of coral reef habitat have undermined reef resilience, making them much more susceptible to current and future climate change (Hughes et al. 2003). Being able to specifically identify the consequences of human actions on reef communities would be a valuable tool in terms of management. Unfortunately, it is not always easy to find the right key, or indicator, that will decode without ambiguity the signal of a human-induced stress on coral reefs.

This article aims to review:

- the major and most frequent human-induced physical disturbances and their consequences on coral reef habitats considering different levels of ecological organisation associated with various spatial scales (colony scale to region scale), and

- the scale-related indicators and conceptual aspects to detect and to measure the effects of these physical disturbances. By physical disturbances, we mean all events that lead to destruction/erosion of the carbonate framework of a colony, community or entire reef.

Within the limit of this article, we do not consider either man-induced non-physical disturbances such as chemical pollution, eutrophication, or thermal stress, nor non-human, natural, physical-perturbations, such as hurricanes, coral-bleaching events, or outbreaks of predators. Furthermore we will not address indirect perturbations such as global human induced greenhouse warming. Only direct perturbations will be specifically identified here.

\section{Multi-scale habitat in coral reef environments}

The habitat of an organism can be intuitively defined as the place where it lives, and which provides food, shelter and living space to the organism. More formally, a habitat can be defined as a spatially-bounded area, with a subset of physical and biotic conditions, within which the density of interacting individuals, and at least one of the parameters of population growth, is different than in adjacent subsets (Morris 2003). Then, habitat must be defined by the species and populations of interest, and in a manner that reflects underlying processes operating at appropriate spatial and temporal scales. Coral habitats can be classified according to an ecological function (e.g., nursery grounds) and/or according to a spatial or structural pattern (e.g., the distribution of living and non-living components). These approaches are not mutually exclusive, since function and structure are intimately linked at all levels of biological organization. A particular organism can occupy different habitats at different stages of its life and according to its activity (growth, foraging, sheltering and reproduction). This vision is compatible with a hierarchical, multi-scale presentation of reef habitats. For example, a colony is a habitat, but 
it is also submitted to a specific hydroclimate, which control a region. Since methods for monitoring and measuring indicators are generally scale-implicit, we propose a presentation by ecological-spatial scales (Fig. 1). This presentation makes easier to link directly a couple \{habitat, disturbance $\}$ with its potential indicators (Sect. 4). Such a hierarchical decomposition is appropriate for complex systems (O'Neill et al. 1989; O’Neill 2001).

\subsection{Level 1: Individual coral colony, community and reefscape}

The level of habitat can be referred as a small-scale level: 1 to $10 \mathrm{~m}$ spatial unit. It corresponds to what most coral reef ecologists refer to when they use the concept of habitat. Individual coral colonies create a microcosm that offers shelter and food for various species. The success of coral recruitment depends upon a variety of environmental factors (temperature, light, sedimentation, salinity, nutrient regime, wave action and type of substrate). The spatial aggregation of coral colonies within a mono- or multi-specific community forms a "reefscape", which can be defined as an architectural unit. Within this unit of typically a width of a few tens of meters, habitats can be diverse, offering living space for various inhabitants (molluscs, crustaceans, fishes, algae, corals, etc.), which are involved in a complex web of ecological interactions.

\subsection{Level 2: Reef zone, whole reef}

We refer to this level of organization as the "meso-scale" level. Spatially, it typically ranges from few tens of meters to few kilometres. Depending on depth and hydrodynamic conditions, reefscape may change quickly or gradually within a reef zone and within the whole reef (Veron 1986). A complex reef may have several reef zones (fringing reef, barrier reef, reef flat, lagoon, patches, outer slope, channel, etc.), each of them potentially presenting several reefscapes. Conversely, a simple reef may have only a couple of reef zones and few reefscapes. Reef zones are large, yet, as a whole, they are under the influence of the same type of environmental or human forcing and will reflect the influence of perturbations in a relatively unimodal way. Thus reef zones are frequently considered as management units in integrated coastal management or monitoring programs.

\subsection{Level 3: Island, region}

We refer to this level of organization as the "large-scale" level. Spatially, it typically ranges from few hundreds of meters to hundred of kilometres. It embodies reef complexes, islands, archipelagos and groups of archipelagos belonging to the same unit in terms of biogeography or hydroclimate. Noteworthy at this scale is that interactions between the reef systems and other ecosystems (land, ocean) are implicit. A biogeography region can also be considered as one scale of habitat, since coral distribution and diversity depend on the environmental factors that trigger coral spawning, on the ocean-circulation patterns that physically control the dispersal of passive larvae and, ultimately, evolutionary processes
(Veron 2000; Achituv and Dubinsky 1990). This scale is relevant here because it is often considered for management purposes. For instance, network of protected areas or conservation actions are defined within an island, a reef tract, or an archipelago under the same jurisdiction.

\section{Human disturbance categories and their effects on coral habitats}

The major anthropogenic disturbances affect the physical structure of coral habitats at each organisational level (Table 1). Here, a disturbance is an event that alters the physical environment and/or limits the availability of essential resources (e.g., available substrate) (Pickett and White 1985). This inventory may not be completely exhaustive, but it highlights the major perturbations that have been documented in coral reefs. Furthermore, it is not straightforward to discriminate the relative contributions of natural or man-induced perturbations to the resulting community structure (Grigg and Dollar 1990; Hatcher et al. 1989) since cascading or convoluted effects are common at various time-scales (Quinn and Dunham 1983; Karlson and Hurd 1993; Adjeroud 1997). This convolution of processes explains why management decisions and actions are not a simple endeavor (Fig. 2).

Coastal development, tourist activities, harvesting pressure, accidents and nuclear/weapon testing are the main stressors (Table 1). The increase of human populations on coastal areas promotes constructions and land reclamation for airports, roads, ports, marinas, houses and hotels. This does not only sacrifice reef zones (meso-scale disturbance), but often requires the extraction of coral boulders (small-scale disturbance) in areas that lack alternative building material (e.g., Brown and Howard 1985; Salvat 1987; White 1987). Land reclamation is not limited to modern or developing spacelimited countries. Traditional way of life of the Kuna Yala Indians in San Blas archipelago (Panama), and limited space on inhabited islands also result in extensive coral mining and "reef flat filling" (Guzman et al. 2003). At small-scale (colony), tourists eager to enjoy coral reefs can have significant effects by trampling, anchoring, snorkelling, diving or boat groundings (Tilmant 1987; Hawkins and Roberts 1992; Clarke et al. 1993; Allison 1996; Jameson et al. 1999; Tratalos and Austin 2001; Zakai and Chadwick-Furman 2002). At smallscale (colony or community), harvesting using destructive fishing methods, such as dynamite or cyanide fishing, "muroami" (driving of fish into large nets attached to the reef) and traps, have a high negative impact (Alcala and Gomez 1987; Eldredge 1987; Gomez and Alcala 1987; Munro et al. 1987; Randall 1987; Johannes and Riepen 1995). Such practices are prohibited in some countries (e.g., Philippines) but laws are not always enforced (Alcala and Gomez 1987). Bombing for military training had a great impact on the reef framework, for instance in Los Vieques Islands (offshore Puerto-Rico). Accidents, which include ship grounding, had a harmful effect on coral reef habitat from colony scale to reef zone (Dollar and Grigg 1981; Hatcher 1984; Hudson and Goodwin 2001). Finally, nuclear testing performed on South Pacific atolls (e.g. Mururoa, Bikini) had significant impacts at meso-scale level 


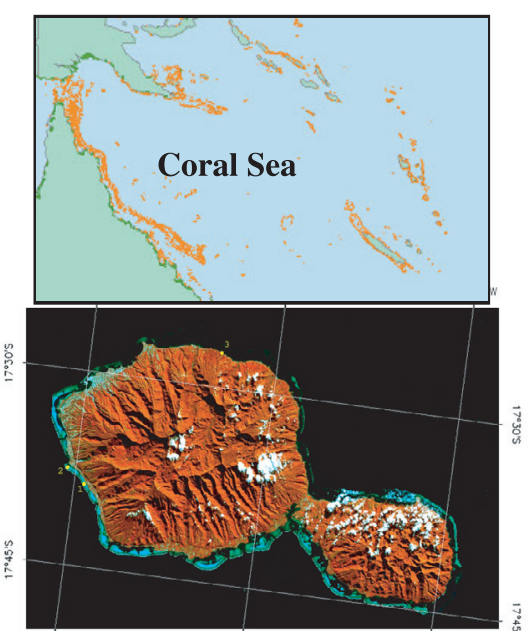

\section{Region}

Group of islands, or archipelagoes exposed to the same hydroclimate

(Metapopulation)

$$
>1: 100000
$$

\section{Island}

Islands, mainland section. Colonies belonging to the same reef complex (group of reefs)

(Subpopulation)

$$
1: 10000-1: 100000
$$

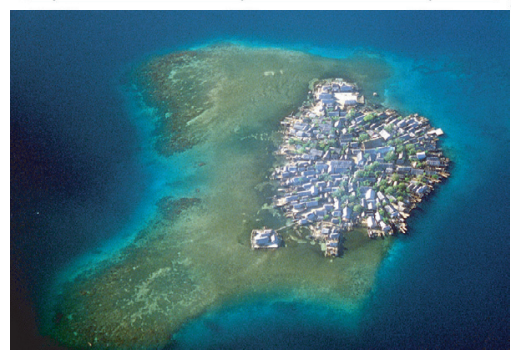

\section{Whole reef}

Set of coral colonies belonging to the same fringing, barrier, patch reef

(Ecosystem)

1:5000 - 1:25000

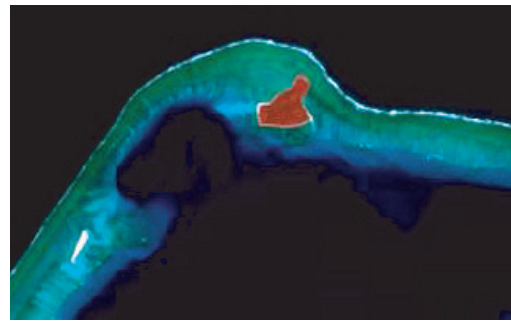

\section{Reef zone}

Set of coral colonies belonging to the same geomorphological unit (reef flat, back reef zone, lagoon, outer reef slope...)

$$
1: 5000-1: 25000
$$

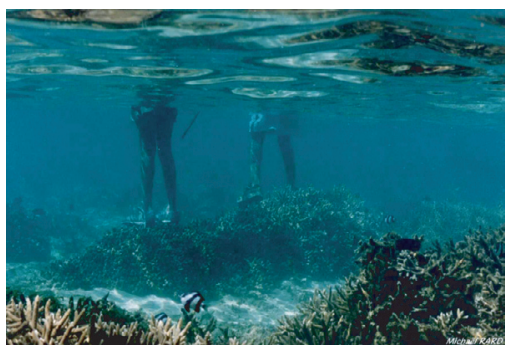

\section{Reefscape}

Set of coral colonies belonging to the same architectural unit

Community/assemblage 1:1000

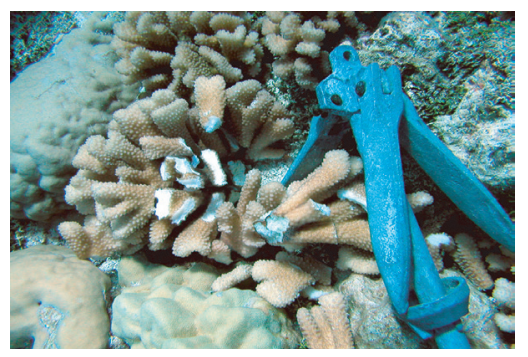

\section{Colony Individual $1: 100$}




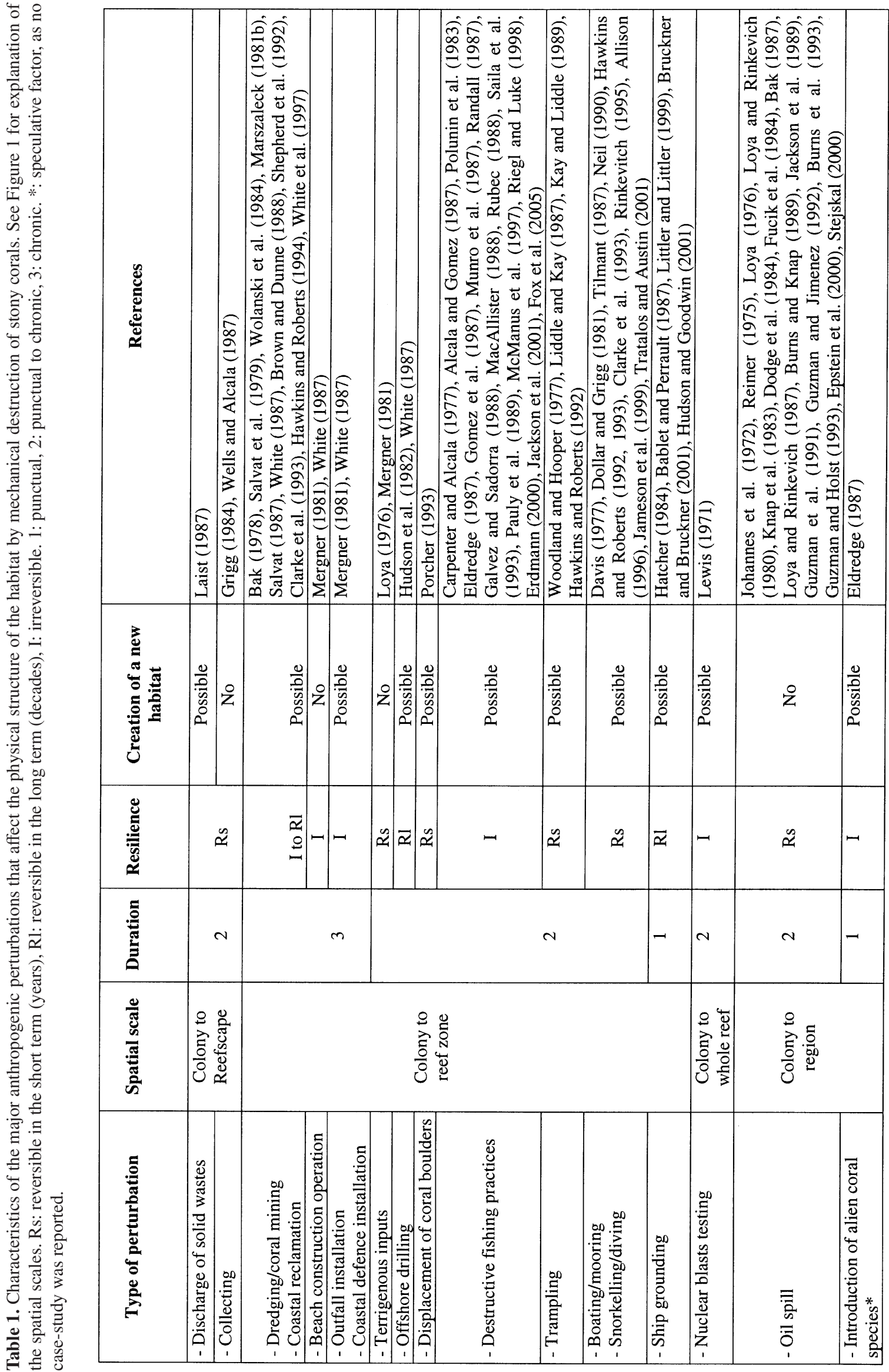




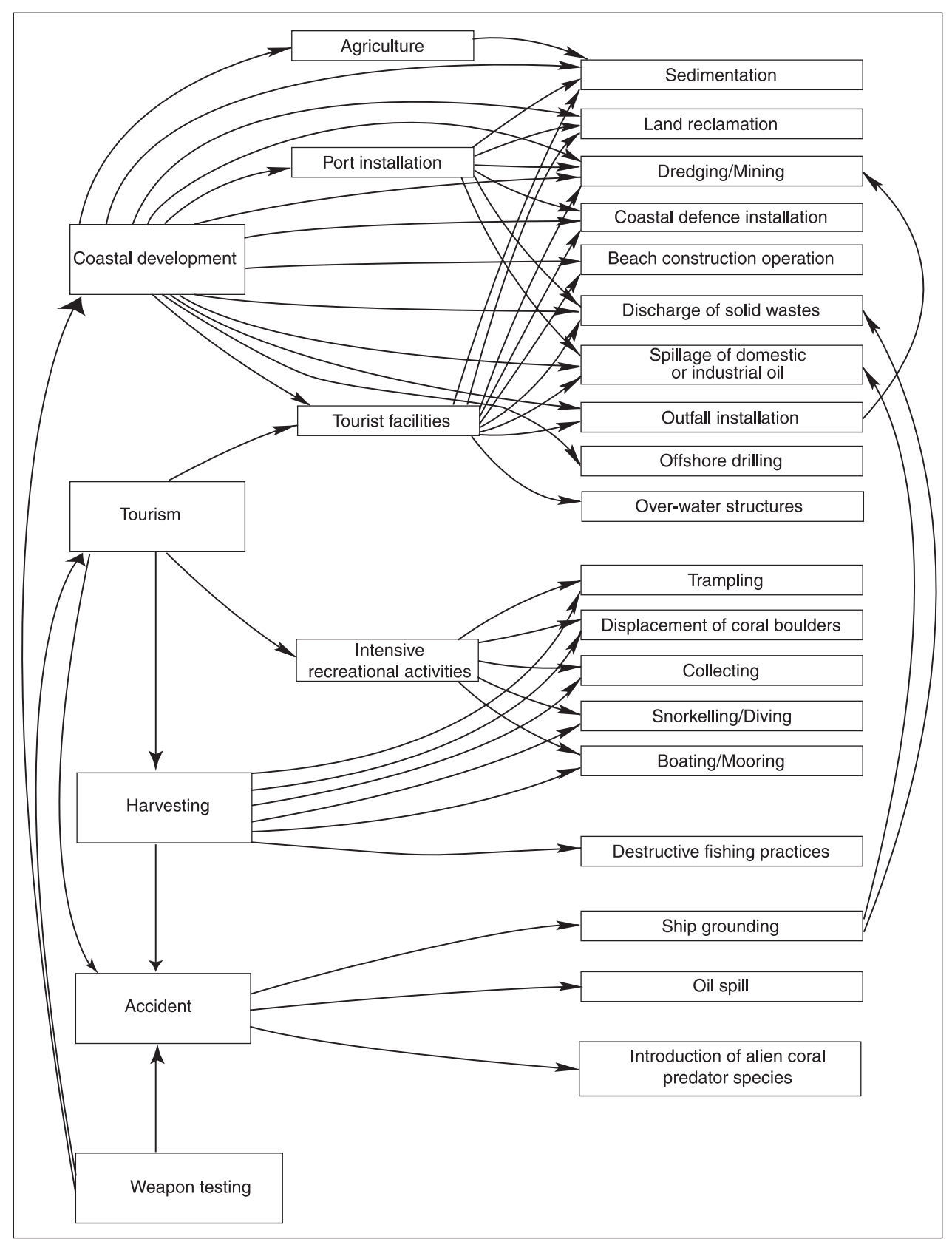

Fig. 2. Cascading causes of coral reef physical degradation. As an example of this "domino effect", nuclear weapons tests done 40 years ago have themselves directly damage the physical foundation of pinnacles or atoll rims, but they are also the initial factor that makes now possible the lucrative wreck-diving activities in "nuclear lagoons" such as Bikini, which itself promote fishing for feeding local and tourist populations and tourist facilities development, which itself enhance the risks of accidents.

on the structure of several sections of the rims and large pinnacles. In Mururoa atoll (French Polynesia), cracks appeared in lagoon bommies and the southern rim collapsed due to the explosion shock wave (Bouchez and Lecomte 1995). In Bikini atoll (Marshall Islands), the first aerial explosions created huge craters along the atoll's rim (Fig. 1).

The human disturbances listed above have various effects that differ in their mode of action, their spatial scale, their intensity and their duration. The same exact disturbance may have a different effect (or perturbation) depending on the moment it strikes the reef and where. For example, dredging and terrigenous inputs, which have important impacts on fringing reef communities of high islands, have generally a negligible impact on the outer slope of high islands and atolls (Salvat et al. 1979; Augustin et al. 1997; Adjeroud et al. 2002; Fabricius 2005). In contrast, diving, ship grounding and nuclear blast testing may affect lagoonal as well as outer reef slope coral communities. Despite their negative effects, some modes of perturbation may effectively create a new coral habitat. This aspect is particularly important for the management and rehabilitation of disturbed areas (Salvat et al. 2002). In general, the effects of disturbances depend on the temporal and 
spatial reference scales under consideration, their frequency, the ecological history of the site (e.g., chronology of the previous perturbations), the structure (growth forms, etc.) of the impacted communities, the geomorphology and depth of the reef zone, the confounding influence of any other physical or biotic stresses (Connell 1978; Hughes 1989; Grigg and Dollar 1990; Karlson and Hurd 1993; Meesters and Bak 1993; Hughes 1994; Bak and Nieuland 1995; Connell et al. 1997).

These perturbations may have short-term or immediate direct consequences, as well as long-term and indirect effects mostly at small and meso-scales. Most of the perturbations, compiled in Table 1, affect coral habitats at these two scales. We have not identified a direct human-induced physical perturbation that is specific to the large-scale level. It is only through repetition or generalisation of small-scale disturbances, throughout a region or an island, that human induced physical perturbations become large-scale level disturbance. Otherwise, there are several examples of meso-scale level disturbances that have second-order large-scale influences. For instance, the dredging of a pass in an atoll is a reef-zone physical disturbance, but the resulting modification of the water exchanges between lagoon and ocean may have significant consequences on the equilibrium of the whole island. Several anthropogenic disturbances may look relatively minor compared to natural disturbances, such as cyclones or submarine earthquakes (Hatcher et al. 1989). However, human impacts, when combined with natural disturbances, may significantly affect the recovery process of a reef, particularly since they are often chronic rather than infrequent (Connell et al. 1997).

Some of the disturbances are well documented (e.g., destructive fishing practices), whereas other were rarely studied (e.g., bombing or nuclear blasts testing) (Table 1). In general, physical disturbances result in a reduction in the three dimensional structural complexity of the reefs, reducing the availability of shelters for associated organisms (Aroson and Swanson 1997). Physical destruction may not necessarily kill coral colonies entirely. However, even partial mortality and weakening may favour pathogens infestation and reduce the reproductive potential of individuals (Hunte and Wittenberg 1992; Ward and Harrison 2000; Hall 2001; Nugues and Roberts 2003). Even if coral colonies are not directly damaged, the sediment and rubbles produced by human activities may cover and bury the coral community in place ("smothering" effect). Discharge of solid wastes and oil spill may also cover, totally or partially, the coral colonies in place. There is no real evidence that oil floating above the corals causes noticeable damage, but one may assume that corals living near the surface can be coated by oil and consequently impacted in their physical structure. For further explanations on the perturbations and their effects, we have listed the most relevant literature.

It is often difficult to estimate the duration of the effects associated to a particular perturbation. In fact, several perturbations, such as trampling, collecting, destructive fishing practices or bombing have effects that may be infrequent or chronic. However, other perturbations, such as dredging and beach construction operation, are often chronic, whereas ship grounding can be considered as infrequent perturbations. The impacted coral communities may be irreversibly damaged, or may recover partially or totally. The resilience (i.e., capacity to recover) of the coral community depends on the characteristics (intensity and duration) of the perturbation and on the initial community or colony structure (Connell et al. 1997). It depends also on functional processes (such as herbivory), and the functional overlap (or redundancy) of multiple species in an ecosystem (Nyström et al. 2000; Nyström and Folke 2001; Belwood et al. 2004), on the availability and abundance of local larvae, and on the connectivity with other reef habitats and larval supply (Obura 2005). The concept of "spatial resilience" is differentiated from that of ecological resilience by recent authors (Nyström and Folke 2001; Bengtsson et al. 2003), most important in terms of the spatial scale over which it is applied. Ecological resilience generally applies to properties within the spatial boundaries of an ecosystem. In coral reef studies, this is generally considered to extend up to tens and sometimes hundred kilometres (Obura 2005). Spatial resilience extends beyond this to include large scale functions and processes beyond boundaries of an ecosystem unit. For a coral reef, this would include the processes of connectivity to other reefs by currents and larval dispersal, large-scale oceanographic phenomena such as upwelling in adjacent system and other features that may occur over hundreds to thousands of kilometres (Obura 2005). Furthermore, chronic and low level perturbations may cause more damage to the reefs in the long term than discrete and highly destructive events, because the former do not allow sufficient time for recovery (Davis 1977; Dustan and Halas 1987; Tilmant 1987). Nevertheless, dredging, coastal reclamation, beach construction operation, and coastal installations generally imply that impacted communities have few chances to return to their initial state (i.e. irreversible impacts) (Table 1). For other discrete and weak perturbations, such as collecting, mooring and boating, or snorkelling and diving, impacted communities may return rapidly (years) to their initial structure. For larger scars, due to large ship grounding for instance, recovery time may be higher (decades). In some case, the extent of the disturbances may not prevent communities to return to their initial structure. For destructive fishing practices, small-scale impacts (e.g., individual blasts) do not alter significantly the community structure, whereas generalisation of these impacts at larger scale (e.g., several densely spaced blasts over large portions of a reef) may eventually alter the community structure and the environment, and thereby greatly reduce the potential and rate of recovery (McManus et al. 1997; Riegl and Luke 1998).

Some perturbations may create a new coral habitat (Table 1). For example, dredging, coastal reclamation, sewage discharge and coastal defence installations, or offshore drilling may create a new substrate that can be colonized by corals, thus forming a habitat for other reef species. Trampling, displacement of coral boulders, boating/mooring, snorkelling/diving, ship grounding, destructive fishing practices, discharge of solid wastes, and nuclear blasts testing may form accumulation of dead and live coral rubbles, which may provide habitat for certain fish species (Riegl and Luke 1998). In contrast, beach construction operations, terrigenous inputs, collecting, and oil spill have never been associated with the creation of new habitats. Historical trajectories of reef degradation extending back thousands of years, provide a powerful 
tool to explain global patterns and causes of ecosystem collapse, as well to predict future ecosystem states, through an understanding of the sequence of species and habitat loss (Pandofi et al. 2003).

\section{The measure of physical disturbances on coral reef habitats}

\subsection{Scale-dependent indicators of disturbance effects on coral reef habitat structure}

The most usual indicators are related to habitat and/or to physical disturbance of habitat (Table 2). Indicator variables are listed according to the spatial scale of the descriptor they are expected to capture. We focus on the three most common categories of descriptors:

- the stony coral itself;

- reef fishes represented by Chaetodontidae among which many species are coral feeders and dependent of the coral reef habitat, and

- the human uses which could have an impact on coral reef habitats. Various variables are proposed as indicators to evaluate the impact of disturbance on these descriptors. We also indicate the methods generally used to obtain data on these variables (see English et al. 1994 for details on the classical methods used to monitor coral reefs), and the sampling unit of the method.

At colony scale (stony corals descriptors), the reproductive output (number of planulae per tissue volume) could decrease after repeated breakage (Rinkevich and Loya 1989; Van Veghel and Bak 1994; Rinkevich 1995). This decrease of spawning rate could be followed by a decrease in recruitment rate (number of new corals settling per substratum unit) (Richmond 1997; Zakaï et al. 2000). Recruitment intensity itself may be a useful measure to check if physically damaged reefs are in a way of recovery or not (Kojis and Quinn 2001). To date, the possibility of using other aspects of coral biology as indicators of environmental stress has seldom been explored. Noteworthy are measurements of coral tissue abrasion (damaged tissue that exposed the underlying intact coral skeleton, according to Riegl and Velmirov 1991; Hawkins et al. 1999; Zakai and Chadwick-Furman 2002) or partial mortality in massive corals (percentage of dead surface area per colony according to Brown and Howard 1985; Nugues and Roberts 2003). Nugues and Roberts (2003) proposed the 50\%threshold in dead coral tissue per colony as a simple stress indicator. Such variables may provide a rapid and effective means of detecting sediment stress on coral reefs, for example after dredging operations.

At reefscape or reef zone scale (corresponding to community/assemblage at ecological level), live coral cover and colony number are widely used in coral reef monitoring programs to assess coral reef health (e.g., Global Coral Reef Monitoring Program, Reef Check). The ratio of standing dead coral cover to total cover of both live and dead corals (Gomez et al. 1994) or linear quotes of live coral cover (>75\%: excellent, 50-75\%: good, $25-50 \%$ : fair, $<25 \%$ : poor) (Gomez and Yap 1988) are also used. Their use as indicators of reef condition in "snapshot" survey is based on the assumption that "healthy" reefs should have high coral cover and coral density (Gomez and Yap 1988; Aronson et al. 1994). However, this assumption could be erroneous in some cases (Thomason and Roberts 1992). Moreover, sites with very high percentage of live coral cover are frequently composed of large monospecific stands of corals, with low coral diversity and spatial complexity (Roberts and Ormond 1987). Nevertheless, in some cases, the percentage of live branching corals or branching associated to live tabular corals has been used to characterise habitat complexity (Chabanet et al. 1997; Lewis 1998). Percentage of live coral cover could be used with other indices such as conservation classes that more accurately predict habitat complexity (Edinger and Risk 2000). Conservation value are estimated using r-K-S (ruderal/competitor/stresstolerators) ternary diagrams based upon the relative abundance of standardized coral morphology categories: Acropora corals as disturbance-adapted ruderals $(r)$, branching non-Acropora corals and foliose corals as competition-adapted $(K)$ and massive and submassive corals as stress-tolerators $(S)$. Then, reefs are classified from class $1(S>60 \%)$ to class 4 (\% r, K, $S$ approximately equal). Other authors also estimated habitat complexity from coral morphological diversity (Roberts and Ormond 1987). Indexes of structural complexity or rugosity (ratio contour tape lengtht on stretched tape lengtht) have been also suggested (Risk 1972; Luckhurst and Luckhurst 1978; Dahl 1988). Williams and Polunin (2000) estimated the structural complexity of the substratum on a 6 point-scale (0: no vertical relief to 5: exceptionally complex with high coral cover and numerous caves and over-hangs). Related also to colony scale, "breakage variables" could be used as an indicator of diving pressure in the form of broken coral rubble (Hawkins and Roberts 1994, 1997) or loose fragments adjacent to branching colonies (Zakai and Chadwick-Furman 2002).

At whole reef scale (corresponding to ecosystem at ecological level), clear-cut zonation patterns in a form of serial change in community structure with an increase of water depth are long-established features of shallow water communities. Undisturbed situations provide clear sequences of community changes along transects, while the sequences appear disrupted after dredging operations (Clarke et al. 1993). Following this example, Clarke et al. (1993) proposed an index (Index of Multivariate Seriation) that measures the degree to which a coral community compares relative to a linear sequence. Furthermore, attributes such as "Reef Quality Index" (quality not acceptable if hard coral cover $<30 \%$, recently broken coral $>5 \%$, recently dead coral $>3 \%$ and coral rubble cover $>5 \%$ according to Jameson 1998) or "Coral Damage Index" (quality not acceptable if broken coral colonies $\geq 4 \%$, coral rubble cover $\geq 3 \%$ according to Jameson et al. 1999, 2001) could be used globally to gauge the severity and extent of physical damages, and focus managers on areas that need dive site management programs (e.g. mooring buoys).

Using fish communities descriptors, Chaetodontidae (butterflyfish) have been proposed as indicator of coral reef "vitality” (e.g. Reese 1981; Sano et al. 1984; Öhman et al. 1998). The underlying simple hypothesis is that since some feed on corals, if corals decline, then populations of corallivorous butterflyfish should also decline or change their feeding 


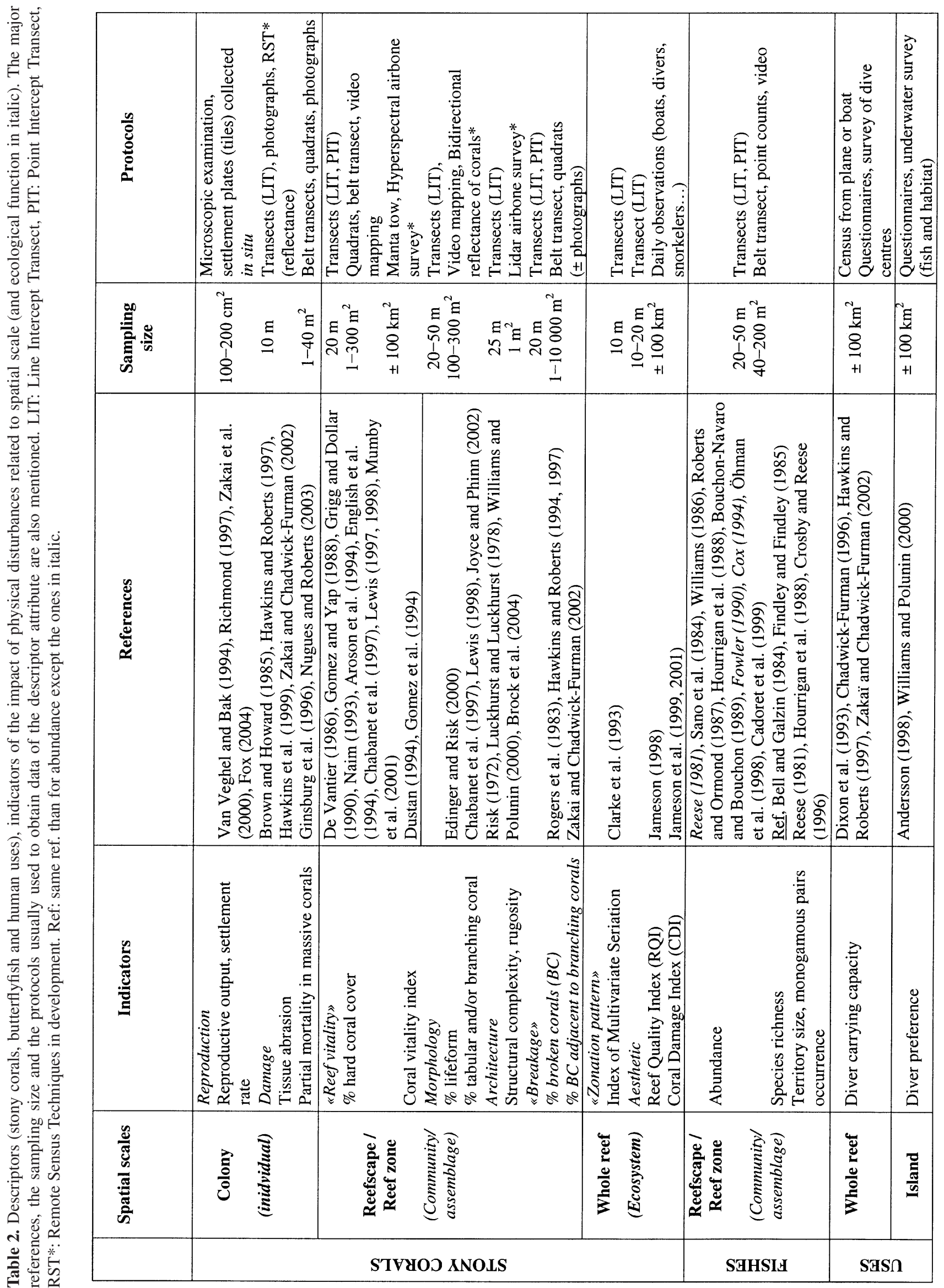


behaviour. However, in some cases, the actual correlation was low (Roberts and Ormond 1987; Fowler 1990). Nevertheless, species richness and abundance of chaetodontids have often been included into monitoring programs since volunteers without specific experience can easily conduct surveys on these easy-to-identify populations (Hodgson 1999; Conand et al. 2000; Crosby and Reese 1996).

The human uses of coral reef ecosystems is represented here by recreational scuba diving activities which is an important and growing component of the tourism market (Moberg and Folke 1999). The diver preferences for certain reef attributes were classified by Williams and Polunin (2000). These authors rank 14 attributes (e.g. "reef structure", "big fish", "variety of fishes", "variety of corals", "coral cover", "unusual fish", "sponges", etc.) on a scale from 0 (not at all important) to 5 (most preferred). Furthermore, some authors used the concept of "diver carrying capacity" which is the number of dives per site and per year that a reef can tolerate without becoming significantly degraded (Dixon et al. 1993; Chadwick-Furman 1996; Hawkins and Roberts 1997). Hawkins and Roberts (1997) suggests that reefs in the Red Sea and Caribbean can sustainably support around 5000-6000 dives per site per year, but that greater levels of use cause a rapid rise in diver damages.

Most of the variables measure disturbance effects on scale ranging from individual to community (Table 2). There is a paucity of indicator variables measuring habitat attributes at large spatial scale. These variables are less common because of the cost linked with this kind of studies and the difficulties to carry them out. Using remote sensing techniques, environmental impacts could be easier to measure at larger scales. For instance, remote sensing observations provide unambiguous measurement of changes in shorelines and alteration of reef zones due to land reclamation, dredging or waste disposal (e.g. the so-called "trash island" in Male atoll, Maldives). Several of these techniques are still largely exploratory and have not been validated on a sufficient number of case studies. Nevertheless, we mention key reports that clearly offer interesting perspectives in measuring synoptically coral mortality, using airborne hyperspectral data (Mumby et al. 2001), reef rugosity using LIDAR, i.e. airborne laser (Brock et al. 2004), habitat diversity and patchiness using high resolution satellite imagery (Andréfouët et al. 2003), and changes in habitat structure using time-series of images (Palandro et al. 2003). In addition, at colony-scale, in situ optical techniques now investigate the possibility to diagnose early a perturbation using changes in the reflectance or fluorescence of the colonies. Changes in optical measurement reveal changes in pigmentation potentially linked to a stress (Yamano et al. 2003). Finally, current research also assesses the variability of colony-scale reflectance according to their morphology (Joyce and Phinn 2002).

\subsection{Strategy and criteria for assessing and monitoring coral reef habitat}

Managers have to consider various options when conceiving an assessment of a coral habitat. Our goal is not to propose an exhaustive guideline on indicator selection, but to provide references and underline key concepts as sequentially presented (Fig. 3).

It is common sense to state that selection of the most appropriate bioindicators for a particular assessment or monitoring program depends on the objectives of that program (Dale and Beyeler 2001). We identified three broad categories of objectives (Fig. 3):

- To monitor trends in habitat conditions across time, in order to measure whether specific management actions improved habitats conditions, or whether the habitat has reached a level of disturbance for which some type of actions are required (Objective O1). The monitoring can be specifically designed to address one pre-identified disturbance, or can target a wide spectrum of disturbances.

- To make a single assessment of the initial status of the environment (Objective O2). This status describes habitat conditions after a perturbation has been identified (e.g. ship grounding), or draws an initial picture of habitat conditions before some type of planed disturbances occur (e.g. dredging). This objective can be a prelude to objective $\mathrm{O} 1$ (monitoring).

- To improve knowledge and use of existing indicators or test new indicators (Objective O3).

This methodological objective is generally designed to improve the cost-effectiveness of currently applied methods. It aims to test experimentally some hypothesis or it tries to identify hypotheses that will be tested afterwards.

In addition, a management plan can be designed specifically to address one type of disturbance (Hypothesis H1), but some organisations have launched general monitoring plan at large scale for an entire region without a specific disturbance in mind (Hypothesis H2). The objectives will have to be carefully considered within these broad limits.

A variety of indicators with different generic properties need to be considered (Jope 2001). Stressor indicators measure the stressor itself (e.g., sediments in the water column after a dredging operation). The drawback is that there is no indication of consequences on the habitat themselves. Exposure indicators measure the amount of stressor to which the habitat is exposed (e.g., number of reef-walkers in a tourist area). These could be used as a diagnostic indicator as they are specific to the stressor. Response indicators measure changes occurring on the habitats (e.g., coral cover); however they do not necessarily identify the cause of the changes. The specificity of a response indicator is a key criterion. Response indicators can be specific and have a threshold or gradual response to a specific type of disturbance. Non-specific indicators will reveal that something is happening but not the causality. However, a range of non-specific indicators may be better than one specific indicator to draw the status of habitats at different scales. Most of the variables or attributes are response indicators (Table 2) as they measure changes occurring in the system (Jope 2001). They provide a better indication of ecological attribute conditions (habitat component), than ecological effects due to a specific disturbance. For example, by the time census methods have detected broken corals, these corals have already suffered damage and further efforts must focus on preventing more damage and death. Conversely, "diver carrying capacity" may be considered as exposure indicator as it measures 


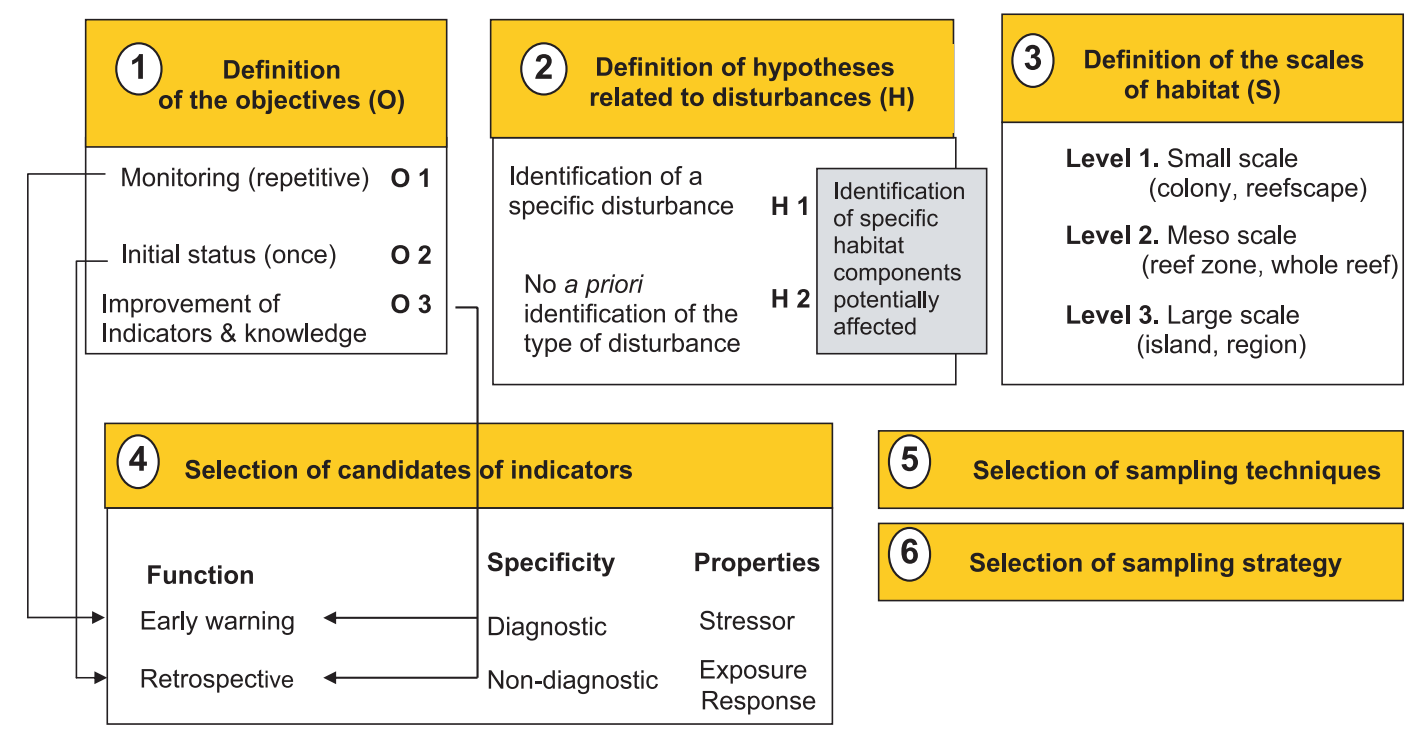

Fig. 3. Framework of sampling design for assessing indicators (e.g. coral reef habitat).

the amount of stressor to which the system is exposed. If specific to the stressor, this indicator may be considered as a diagnostic indicator. Non-diagnostic indicators may reflect changes (Rapport et al. 1985; Jope 2001), but not specifically to one of the disturbances (Table 1 ).

To complete this general classification of indicators, other properties such as sensitivity (the capacity to reveal gradations in response to stress) are of interest (Jameson 1998). This anticipatory quality specifies whether the indicator can provide early-warning signal (useful in case of monitoring trends in environmental conditions over the time), or is retrospective, providing evidence of ecosystem change after the change has occurred (Rapport et al. 1985).

The scale of work is one of the main considerations. Scale in this context depends directly on the objectives and the hypotheses which depend on the considered specific disturbance. Willingness to draw a general picture of coral habitats (Objective O2) without specific disturbances in mind (Hypothesis H2) will imply that a wide range of scale needs to be addressed. For instance, reefscape (or community) to regions can be studied by multiplying the numbers of regional sites where community measurements will be performed. Unfortunately, no single indicator is applicable directly across all spatial scales of concern (Dale and Beyeler 2001). Therefore, combining indicators at different levels of the biological organisation represents an optimal strategy, because these measures serve different purposes, from individual to communities (Hallock et al. 2004). Measures on colony potentially provide the earliest warning of possible deterioration while measures on community give a better indication of the ecological importance and magnitude of the disturbances and their consequences on communities including humans (Rapport et al. 1985; Underwood and Peterson 1988). Indicator selection depends on several additional criteria: the intrinsic quality of the measure itself (depending of the sampling techniques and of the choice of the variable) and the "effectiveness" that gather sampling strategy and the statistical analysis.

\subsection{A hierarchical concept of disturbance in coral reefs in perspectives}

Using a multi-scale approach allows to present the various indicators of (physical) disturbances in a logical suite. However, there is still a lack of explicit relationship between the observed physical impacts on reefs and what these impacts means in terms of alteration of the biological processes occurring on the reef. Another framework focussing on ecosystem functions and integrating the notions of disturbance, levels of organisation, scale, and indicators of perturbations could be a next logical step. Pickett et al. (1989) have proposed such a conceptual framework. By organising each ecological question within a so-called hierarchical model, they distinguish among entities (the object of interest, susceptible of being disturbed), function (set of interactions among entities), and structure (resulting complex of interacting entities). Though conceptually interesting and theoretically better suited to analyse multi-stressor effects throughout different ranges of scales and functions, the design and selection of indicators remain quite problematic. It is definitely recommended that scientists try to visualize the integration of methods within such conceptual frameworks (Hallock et al. 2004). However, the amount of indicators practical for managers remains limited, but new developments still occur. For instance, recent advances in molecular biology should aid in the accurate diagnostic of coral condition by "visualizing" coral stress using Molecular Biomarker System (MBS) or gene expression. For the first step, MBS was use to assess the physiological status of coral challenged under heat stress, using specific cellular and molecular parameters (Downs et al. 2000). However, transplantation experiments must be conducted to examine how stressors in natural populations induce gene expression and to determine whether these potential diagnostic indicators are effective and specific.

\section{Conclusion}

Indicators are essential tools for monitoring the state of the coastal environment. They can inform managers and policy 
makers of the effectiveness of strategies in achieving sustainability and need to be based on rigorous scientific, social and economic research. However, the suite of options for managers is limited. This review shows that the majority of the indicators of human-induced physical disturbances are nonspecific. They can be categorized in few categories based on their properties, but they can't solve all problems. We followed a multi-scale discussion which eventually shows the difficulties for the managers and scientists to have a continuum of answers and indicators across space and time. Tools are needed to identify and rank coral responses to multiple stressors and to determinate which stressors having the greatest effects. Theoretically, a hierarchical scheme could be a logical new integrating scheme since they target functions across scales, but similar models are still in their infancy in the case of coral reef ecosystems. On a practical standpoint, managers and policymakers still need to understand the effects of man-induced disturbances, be able to properly assess these damages, and develop subsequent restoration and conservation efforts on reefs under their stewardship.

Acknowledgements. This review paper was initiated after a workshop on bio-indicators (Nouméa, 2002) funded by the French Programme National d'Environnement Côtier.

\section{References}

Achituv Y., Dubinsky Z., 1990, Evolution and zoogeography of coral reefs. In: Dubinsky Z. (Ed.), Ecosystems of the world, Elsevier, pp. 1-9.

Adjeroud M., 1997, Factors influencing spatial patterns on coral reefs around Moorea, French Polynesia. Mar. Ecol. Prog. Ser. 159, 105-119.

Adjeroud M., Augustin D., Galzin R., Salvat B., 2002, Natural disturbances and interannual variability of coral reef communities on the outer slope of Tiahura (Moorea, French Polynesia): 1991 to 1997, Mar. Ecol. Prog. Ser. 237, 121-131.

Alcala A.C., Gomez E.D., 1987, Dynamiting coral reefs for fish: a resource-destructive fishing method. In: Salvat B. (Ed.), Human impacts on coral reefs: facts and recommendations. Antenne Museum EPHE, French Polynesia, pp. 51-60.

Allison W.R., 1996, Snorkeler damage to reef corals in the Maldive Islands. Coral Reefs 15, 215-218.

Andersson J., 1998, The value of coral reefs for the current and potential tourism industry in Unguja. In: Johstone L., Francis C., Muhando C. (Eds.), Coral Reefs: values, Threats and Solutions. Proc. Nat. Conf. on coral reefs, Nairobi, Kenya, pp. 81-90.

Andréfouët S., Kramer P., Torres-Pulliza D., Joyce K.E., Hochberg E.J., Garza-Perez R., Mumby P.J., Riegl B., Yamano H., White W.H., Zubia M., Brock J.C., Phinn S.R., Naseer A., Hatcher B.G., Muller-Karger F.E., 2003, Multi-sites evaluation of IKONOS data for classification of tropical coral reef environments. Remote Sens. Environ. 88, 128-143.

Aroson R.B., Swanson D.W., 1997, Evolutionary paleoecology of Caribbean reef coral. In: Allmon W.D. and Bottjer D.J. (Eds). Evolutionary paleoecology: the ecological context of macroevolutionary change. Columbia University Press, New York, pp. 171-233.

Aroson R.B., Edmunds P.J., Precht W.F., Swanson D.W., Levitan D.R., 1994, Large-scale, long term monitoring of Caribbean coral reefs: simple, quick, inexpensive techniques. Atoll Res. Bull. 421.
Augustin D., Galzin R., Legendre P., Salvat B., 1997, Variation interannuelle des peuplements récifaux du récif-barrière de Tiahura (île de Moorea, Polynésie française). Oceanol. Acta 20, 743-756.

Bablet J.P., Perrault G.H., 1987, Effects on a coral environment of a nuclear detonation. In: Salvat B. (Ed.), Human impacts on coral reefs: facts and recommendations. Antenne Museum EPHE, French Polynesia, pp. 151-163.

Bak R.P.M., 1978, Lethal and sublethal effects of dredging on reef corals. Mar. Pollut. Bull. 9, 14-16.

Bak R.P.M., 1987, Effects of chronic oil pollution on a Caribbean coral reef. Mar. Pollut. Bull. 18, 534-539.

Bak R.P.M., Nieuwland G., 1995, Long-term changes in coral communities along depth gradients over leeward reefs in the Netherlands Antilles. Bull. Mar. Sci. 56, 609-619.

Bell P.R.F., 1992, Eutrophication and coral reefs-some examples in the Great Barrier Reef lagoon. Water. Res. 26, 553-568.

Bell J.D., Galzin R. 1984, Influence of live coral cover on coral-reef fish communities. Mar. Ecol. Prog. Ser. 15, 265-274.

Bellwood D.R., Hughes T.P., Folke C., Nyström M., 2004, Confronting the coral reef crisis. Nature 429, 827-833.

Bengtsson J., Angelstam P., Elmqvist T., Emanuelson U., Folke C., Ihse M., Moberg F., Nystrom M., 2003, Reserves, resilience and dynamic landscape. Ambio 32, 389-396.

Berg H., Öhman M., Troëng S., Linden O., 1998, Environmental economics of coral reef destruction in Sri Lanka. Ambio 27, 627-634.

Bouchez J., Lecomte R., 1995, Les atolls de Mururoa et de Fangataufa (Polynésie française), II : les experimentations nucléaires, effets mécaniques, lumino-thermiques, électromagnétiques. Masson, Paris.

Bouchon Navaro Y., Bouchon C. 1989, Correlations between chaetodontid fishes and coral communities of the Gulf of Aqaba (Red Sea). Environ. Biol. Fish. 25, 47-60.

Brock J., Wright C., Clayton T., Nayegandhi A., 2004, Optical rugosity of coral reefs in Biscayne National Park, Florida. Coral Reefs 23, 48-59.

Brown B.E., Howard L.S., 1985, Assessing the effects of "stress" on reef corals. Adv. Mar. Biol. 22, 1-63.

Brown B.E., Dunne R.P., 1988, The impact of coral mining on coral reefs in the Maldives. Environ. Conserv. 15, 159-165.

Bruckner A.W., Bruckner R.J., 2001, Condition of restored Acropora palmata fragments off Mona Island, Puerto Rico, 2 years after the Fortuna Reefer ship grounding. Coral Reefs 20, 235-243.

Bruggeman J.H., 1994, Parrotfish grazing on coral reefs: a trophic novelty. PhD Univ. Groningen.

Burns K.A., Knap A.H., 1989, The Bahia Las Minas oil spill hydrocarbon uptake by reef building corals. Mar. Pollut. Bull. 20, 391-398.

Burns K.A., Ehrhardt M.G., Howes B.L., Taylor C.D., 1993, Subtidal benthic community respiration and production near the heavily oiled Gulf coast of Saudi Arabia. Mar. Pollut. Bull. 27, 199-205.

Cadoret L., Adjeroud M., Tsuchiya M. 1999, Spatial distribution of chaetodontid fish in coral reefs of the Ryukyu Islands, southern Japan. J. Mar. Biol. Assoc. UK 79, 725-735.

Carpenter K.E., Alcala A.C., 1977, Philippines coral reef fisheries resources. Part II. Muro-Ami and Kayakas reef fisheries, benefit or bane? Philipp. J. Fish. 15, 217-235.

Chabanet P., Ralambondrainy H., Amanieu M., Faure G., 1997, Relationship between coral reef substrata and fish. Coral Reefs 16, 93-102.

Chadwick-Furman N.E., 1996, Effects of scuba diving on coral reef invertebrates in the U.S. Virgin Islands: implications for management of diving tourism. Proc. 6th Int. Coelenterate Bio. Symp., Amsterdam. 
Clarke K.R., Warwick R.M., Brow B.E., 1993, An index showing breakdown of seriation, related to disturbance, in a coral-reef assemblage. Mar. Ecol. Prog. Ser. 102, 153-160.

Conand C., Chabanet P., Bigot L., Quod J.P., 2000, Guidelines for coral reef monitoring in the south west region of the Indian Ocean. Handbook PRE/COI, 27.

Connell J.H., 1978, Diversity in tropical rain forests and coral reefs. Science 199, 1302-1310.

Connell J.H., Hughes T.P., Wallace C.C., 1997, A 30-year study of coral abundance, recruitment, and disturbance at several scales in space and time. Ecol. Monogr. 67, 461-488.

Constanza R., D'Arge R., deGroot R., Farber S., Grasso M., Hannon B., Limburg K., Naeem S., O’Neill R., Paruelo J., Raskin R., Sutton P., van den Belt M., 1997, The value of the world's ecosystem services and natural capital. Nature 387, 256.

Cox E.F., 1994, Resource use by corallivorous butterflyfishes (family Chaetodontidae) in Hawaii. Bull. Mar. Sci. 54, 535-545.

Crosby M.P., Reese E.S., 1996, A manual for monitoring coral reefs with indicator species: butterflyfishes as indicators of change on Indo-Pacific reefs. Silver Spring, MD: Office of Ocean and Coastal Resource Management, National Oceanic and Atmospheric Administration, 45 p.

Dahl A.L., 1988, Surface area in ecological analysis: quantification of benthic coral-reef algae. Mar. Biol. 23, 239-249.

Dale V.H., Beyeler S.C., 2001, Challenges in the development and use of ecological indicators. Ecol. Indic. 1, 3-10.

Davis G.E., 1977, Anchor damage to a coral reef on the coast of Florida. Biol. Conserv. 11, 29-34.

De Vantier L.M., 1986, Studies in the assessmant of coral reef ecosystems. In: Brown B.E. (Ed.) "Human induced damage to coral reefs". Unesco Rep. Marine Science 40, 99-111.

Dixon J.A, Scura L.F., van't Hof T., 1993, Meeting ecological and economic goals: marine parks in the Caribbean. Ambio 22, 117-125.

Dodge R.E., Wyers S.C., Frith H.R., Knap A.H., Smith S.R., Sleeter T.D., 1984, The effects of oil and oil dispersants on the skeletal growth of the hermatypic coral Diploria strigosa. Coral Reefs 3, 191-198.

Dollar S.J., Grigg R.W., 1981, Impact of Kaolin clay spill on a coral reef in Hawaii. Mar. Biol. 65, 269-276.

Done T.J., 1992, Phase shifts in coral reef communities and their ecological significance. Hydrobiologia 247, 121-132.

Done T.J., Ogden J.C., Wiebe W.J., Rosen R.B., 1996, Biodiversity and ecosystem function of coral reefs. In: Mooney H.A., Cusman J.H., Medina E., Sala O.E., Schulze E.D. (Eds.), Functional roles of biodiversity: global perspectives. Wiley and Sons Ltd, London, pp. 393-423.

Downs C.A., Mueller E., Philipps S., Fauth J.E., Woodley C.M., 2000, A molecular biomarker system for assessing the health of coral (Montastrea faveolata) during heat stress. Mar. Biotechnol. 2, 533-544.

Dustan P., Halas J.C., 1987, Changes in the reef-coral community of Carysfort Reef, Key Largo, Florida, 1974 to 1982. Coral Reefs 6, 91-106.

Dustan P., 1994, Developing methods for assessing coral reef vitality: a tale of two scales. Proc. Colloq. Global aspects of coral reefs: health, hazards and history, pp. 38-45.

Edinger P., Risk M., 2000, Reef classification by coral morphology predict coral reef conservation value. Biol. Conserv. 92, 1-13.

Eldredge L.G., 1987, Poisons for fishing on coral reefs. In: Salvat, B. (Ed), Human impacts on coral reefs: facts and recommendations. Antenne Museum EPHE, French Polynesia, pp. 61-66.
English S., Wilkinson C., Baker V., 1994, Survey manual for tropical marine resource. Australian Institute of Marine Science.

Epstein N., Bak R.P.M., Rinkevich B., 2000, Toxicity and third generation dispersants and dispered Egyptian crude oil on Red Sea coral larvae. Mar. Pollut. Bull. 40, 497-503.

Erdmann M.V., 2000, Destructive fishing practices in Indonesian seas. In: Sheppard C. (Ed.), Seas at the millenium: an environmental evaluation. Pergamon, Amsterdam, pp. 392-393.

Fabricius K.E., 2005, Effects of terrestrial runoff on the ecology of corals and coral reefs: review and synthesis. Mar. Pollut. Bull. 5, 125-146.

Findley J.S., Findley M.T., 1985, A search for pattern in butterfly fish communities. Am. Nat. 126, 800-816.

Fowler A.J., 1990, Spatial and temporal patterns of distribution and abundance of chaetodontid fishes at One Tree Reef, southern GBR. Mar. Ecol. Prog. Ser. 64, 39-53.

Fox H., 2004, Coral recruitment in blasted and unblasted sites in Indonesia: assessing rehabilitation potential. Mar. Ecol. Prog. Ser. 269, 131-139.

Fox H.E., Mous P., Pet J., Muljadi A., Caldwell, R.L., 2005, Experimental assessment of coral reef rehabilitation following blast fishing. Conserv. Biol.19, 98-107.

Fucik K.W., Bright T.J., Goodman K.S., 1984, Measurements of damage, recovery, and rehabilitation of coral reefs exposed to oil. In: Cairns J., Buikema A.L. (Eds.), Restoration of habitats impacted by oil spills. Butterworth, London, pp. 115-133.

Galvez R., Sadorra M.S., 1988, Blast fishing: a Philippine case study. Trop. Coast. Area Manage. 3, 9-10.

Gattuso J.P., Pichon M., Delesalle B., Frankignoulle M., 1993, Community metabolism and air-sea $\mathrm{CO} 2$ fluxes in a coral reef ecosystem (Moorea, French Polynesia). Mar. Ecol. Prog. Ser. 96, 259-267.

Gattuso J.P., Allemand D., Frankignoulle M., 1999, Interactions between the carbon and carbonate cycles at organism and community level in coral reefs: a review on process and control by the carbonate chemistry. Am. Zool. 39, 160-183.

Ginsburg R.N., Bak R.P.M., Kiene W.E., Gischler E., Kosmynin V., 1996, Rapid assessmentof of reef condition using coral vitality. Reef Encounter 19, 12-14.

Gomez E.D., Alcala A.C., Yap H.T., 1987, Other fishing methods destructive to coral. In: Salvat B. (Ed.), Human impacts on coral reefs: facts and recommendations. Antenne Museum EPHE, French Polynesia, pp. 67-75.

Gomez E.D., Yap H.T., 1988, Monitoring reef condition. In: Kenchington R.A. and Hudson B. (Ed.), Coral reef management handbook UNESCO regional office for science and technology for southeast Asia (ROSTSEA), Jakarta, pp. 171-178.

Gomez E.D., Alino P.M., Yap H.T., Licuanan W.Y., 1994, A review of the status of Philippines reefs. Mar. Pollut. Bull. 29, 62-68.

Goreau T.F., 1959, The physiology of skeleton formation in corals. I. A method for measuring the rate of calcium deposition by corals under different conditions. Biol. Bull. 116, 59-75.

Grigg R.W., 1983, Community structure, succession and development of coral reefs in Hawaii. Mar. Ecol. Prog. Ser. 11, 1-14.

Grigg R.W., 1984, Resource management of precious corals: a review and application to shallow water reef building corals. Mar. Ecol. 5, 57-74.

Grigg R.W., Dollar S.J., 1990, Natural and anthropogenic disturbance on coral reef ecology. In: Dubinsky Z. (Eds.), Ecosystems of the world 25, Coral reefs. Elsevier, Amsterdam, pp. 439-452.

Guzman H.M., Jimenez C.E., 1992, Contamination of coral reefs by heavy metals along the Caribbean coast of Central America (Costa Rica and Panama). Mar. Pollut. Bull. 24, 554-561. 
Guzman H.M., Holst I., 1993, Effects of chronic oil-sediment pollution on the reproduction of the Caribbean reef coral Siderastrea siderea. Mar. Pollut. Bull. 26, 282.

Guzman H.M., Castillo A., 2003, Natural disturbances and mining of Panamanian coral reefs by indigenous people. Conserv. Biol. 17, 1396-1401.

Guzman H.M., Jackson J.B.C., Weil E., 1991, Short-term ecological consequences of a major oil spill on Panamanian subtidal reef corals. Coral Reefs 10, 1-12.

Hall V.R., 2001, The response of Acropora hyacinthus and Montipora tuberculosa to three different types of colony damage: scraping injury, tissue mortality and breakage. J. Exp. Mar. Biol. Ecol. 264, 209-223.

Hallock P., Barnes K., Fisher E.M., 2004, Coral-reef risk assessment from satellites to molecules: a multi-scale approach to environmental monitoring and risk assessment of coral reefs. Environ. Micropaleont. Microbiol. Meiobenthol. 1, 11-39.

Hatcher B.G., 1984, A maritime accident provides evidence for alternate stable states in benthic communities on coral reefs. Coral Reefs 3, 199-204.

Hatcher B.G., Johannes R.E., Robertson, A.I., 1989, Review of research relevant to the conservation of shallow water tropical marine ecosystems. Oceanogr. Mar. Biol. Ann. Rev. 27, 337-414.

Hawkins J.P., Roberts C.M., 1992, Effects of recreational SCUBA diving on fore-reef slope communities of coral reefs. Biol. Conserv. 62, 171-178.

Hawkins J.P., Roberts C.M., 1993, Effects of recreational SCUBA diving on coral reefs: trampling on reef-flat communities. J. Appl. Ecol. 30, 25-30.

Hawkins J.P., Roberts C.M., 1994, The growth of coastal tourism in the Red Sea: present and future effect on coral reefs. Ambio 23, 503-508.

Hawkins J.P., Roberts C.M., 1997, Estimating the carrying capacity of coral reef for scuba diving. Proc. 8th Int. Coral Reef Symp. 2, 1923-1926.

Hawkins J.P., Roberts C.M., VanHof T., deMeyer K., Tratalos J., Aldam C., 1999, Effects of recreational scuba diving on Caribbean coral and fish communities. Conserv. Biol 13, 888-897.

Hodgson G., 1999, A global assessment of human effects on coral reefs. Mar. Pollut. Bull. 38, 345-355.

Hoegh-Guldberg O., 1999, Climate change, coral bleaching and the future of the world's coral reefs. Mar. Freshw. Res. 50, 839-866.

Hourigan T.F., Tricas T.C., Reese E.S., 1988, Coral Reef Fishes as Indicators of Environmental Stress in Coral Reefs. In: Soule, D. F., Kleppel, G. S. (Eds.), Marine Organisms as Indicators. Springer-Verlag, pp. 107-135.

Hudson J.H., Goodwin W.B., 2001, Assessment of vessel grounding injury to coral reef and seagrass habitats in the Florida Keys National Marine Sanctuary, Florida: protocol and methods. Bull. Mar. Sci. 69, 509-516.

Hudson J.H., Shinn E.A., Robbin D.M., 1982, Effects of offshore oil drillings on Philippine reef corals. Bull. Mar. Sci. 32, 890-908.

Hughes T.P., 1989, Community structure and diversity of coral reefs: the role of history. Ecology 70, 275-279.

Hughes T.P., 1994, Catastrophes, phase shifts and large scale degradation of a Caribbean coral reef. Science 265, 1547-1551.

Hughes T.P., Connell J.H., 1999, Multiple stressors on coral reefs: a long-term perspective. Limnol Oceanogr 44, 932-940.

Hughes T.P., Baird A., Belwood D.R., Card M., Connolly S.R., Folke C., Grosberg R., Hunte W., Wittenberg M., 1992, Effects of eutrophication and sedimentation on juvenile corals. II Settlement. Mar. Biol. 114, 625-631.
Hutchings P., 1986, Biological destruction of coral reefs: a review. Coral Reefs 4, 239-252.

Jackson J.B.C., Cubit J.D., Keller B.D., Batista V., Burns K., Caffey H.M., Caldwell R.L., Garrity S.D., Getter C.D., Gonzalez C., Guzman, E.M. Kaufmann, K.W. Knap, A.H. Levings, S.C. Marshall, M.J. Steger R., Thompson R.C., Weil E., 1989, Ecological effects of a major oil spill on Panamanian coastal marine communities. Science 243, 37-44.

Jackson J.B.C., Kirby M., Berger W., Bjorndal K., Botsford L., Bourque B., Bradbury R., Cooke R., Erlandson J., Estes J., Hughes T., Kidwell S., Lange C., Lenihan H., Pandolfi J., Peterson C., Steneck R., Tegner M., Warner R., 2001, Historical overfishing and the recent collapse of coastal ecosystem. Science 293, 629-638.

Jameson S.C., 1998, Twelve reefs at risk: red Sea Riviera. In: Bryant D., Burke L., Mc Manus J., Spalding M. (Eds.), Reefs at risk: a map based indicator of potential threats of the world's coral reefs. World Resources Institute, Washington DC.

Jameson S.C., Ammar M.S., Saadalla E., Mostafa H.M., Riegl B., 1999, A coral damage index and its application to diving sites in the Egyptian Red Sea. Coral Reefs 18, 333-339.

Jameson S.C., Erdmann M.V., Karr J.R., Potts K.W., 2001, Charting a course toward diagnostic monitoring: a continuing review of coral reef attributes and a research strategy for creating coral reef indexes of biotic integrity. Bull. Mar. Sc. 69, 701-744.

Johannes R.E., Maragos J.E., Coles S.L., 1972, Oil damaged corals exposed to air. Mar. Pollut. Bull. 3, 29-30.

Johannes R.E., Riepen M., 1995, Environmental, Economic, and Social implications of the live reef fish trade in Asia and the Western Pacific. Report to the Nature Conservancy and the South Pacific Forum Fisheries Agency.

Jope K.L., 2001, An approach to identifying "vital signs" of ecosystem health. In: Harmon D. (Ed.), Proc. 11th Conf. Research and resource management in parks and on public lands, pp. 399-406.

Joyce K.E., Phinn S.R., 2002, Bi-directional reflectance of corals. Int. J. Remote Sensing 23, 389-394.

Karlson R.H., Hurd L.E., 1993, Disturbance, coral reef communities, and changing ecological paradigms. Coral Reefs 12, 117-125.

Kay A.M., Liddle M.J., 1989, Impact of human trampling in different zones of a coral reef flat. Environ. Manage. 4, 509-520.

Kinsey D.W., 1985, Metabolism, calcification and carbon production. I. System level studies. Proc. 5th Int. Coral Reef Symp. 4, 505-526.

Kleypas J.A., Buddemeier R.W., Gattuso J.P., 2001, The future of coral reefs in an age of global change. Int. J. Earth Sci. 90, 426-437.

Knap A.H., Sleeter T.D., Dodge R.E., Wyers S.C., Frith H.E., Smith S.R., 1983, The effects of oil spills and dispersant use on corals. Oil Petrochem. Pollut. 1, 157-169.

Knutson T.R., Tuleya R.E., Kurihara Y., 1998, Simulated increase of hurricane intensities in a $\mathrm{CO}_{2}$ warmed climate. Science 279, 1018-1019.

Kojis B.L., Quinn N.J., 2001, The importance of regional differences in hard coral recruitment rates for determining the need for coral restoration. Bull. Mar. Sc. 69, 967-974.

Laist D.W., 1987, Overview of the biological effects of lost and discarced plastic debris in the marine environment. Mar. Pollut. Bull. $18,319-326$.

Lewis J.B., 1971, Effects of crude oil and oil spill dispersant on reef corals. Mar. Pollut. Bull. 2, 59-62.

Lewis A.R., 1997, Effects of experimental coral disturbance on the structure of fish community on large patch reefs. Mar. Ecol. Prog. Ser. 161, 37-50. 
Lewis A.R., 1998, Effects of experimental coral disturbance on the population dynamic of fishes on large patch reefs. J. Exp. Mar. Biol. Ecol. 230, 91-110.

Liddle M.J., Kay A.M., 1987, Resistance, survival and recovery of trampled coral on the Great Barrier Reef. Biol. Conserv. 42, 1-18.

Littler M.M., Littler D.S., 1999, Disturbances due to cyclone Gavin parallel those caused by a ship grounding. Coral Reefs 18, 146.

Loya Y., 1976, Recolonization of Red Sea corals affected by natural catastrophes and man-made perturbations. Ecology 57, 278-289.

Loya Y., Rinkevitch B., 1980, Effects of oil pollution on coral reef communities. Mar. Ecol. Prog. Ser. 3, 167-180.

Loya Y., Rinkevitch B., 1987, Effects of petroleum hydrocarbons on corals. In: Salvat B (Ed.), Human impacts on coral reefs: facts and recommendations. Antenne Museum EPHE, French Polynesia, pp. 91-102.

Luckhurst B., Luckhurst K., 1978, Diurnal space utilization in coral reef communities. Mar. Biol. 49, 325-332.

Marszaleck D.S., 1981a, Sewage and eutrophication. In: Salvat B. (Ed.), Human impacts on coral reefs: facts and recommendations. Antenne Museum EPHE, French Polynesia, pp. 77-90.

Marszaleck D.S., 1981b, Impact of dredging on a subtropical reef community, southeast Florida, USA. Proc. 4th Int. Coral Reef Symp. 1, 147-153.

McAllister D.E., 1988, Environmental, economic and social costs of coral reef destruction in the Philippines. Galaxea 7, 161-178.

McManus J.W., Nanola C.L., Reyes, R.B., 1997, Effects of some destructive fishing methods on coral cover and potential rates of recovery. Environ. Manage. 21, 69-78.

Meesters E.H., Bak R.P.M., 1993, Effects of coral bleaching on tissue regeneration potential and colony survival. Mar. Ecol. Prog. Ser. 96, 189-198.

Mergner H., 1981, Man-made influences on and natural changes in the settlement of the Aqaba reefs (Red Sea). Proc. 4th Int. Coral Reef Symp. 1, 193-207.

Moberg F., Folke C., 1999, Ecological goods and services of coral reef ecosystems. Ecol. Econ. 29, 215-233.

Morris D.W., 2003, Toward an ecological synthesis: a case for habitat selection. Oecologia 136: 1-13.

Mumby P.J., Chisholm J.R.M., Clark C.D., Hedley J.D., Jaubert J., 2001, A bird-eye view of the health of coral reefs. Nature 413, 36.

Munro J.L., Parrish J.D., Talbot F.H., 1987, The biological effects of intensive fishing upon coral reef communities. In: Salvat B. (Ed.), Human impacts on coral reefs: facts and recommendations. Antenne Museum EPHE, French Polynesia, pp. 41-49.

Naim O., 1993, Seasonal responses of a fringing reef community to eutrophication (Reunion island, Western Indian Ocean). Mar. Ecol. Prog . Ser. 99, 307-315.

Naim O., Cuet P., Mangar V., 2000, Coral reefs of the Mascarene archipelago. In: McClanahan T.R., Sheppard C., Obura D.O. (Eds.), Coral reefs of the Indian Ocean: their Ecology and Conservation, Oxford University Press, pp. 353-381.

Neil D., 1990, Potential of corals stress due to sediment resuspension and deposition by reef walkers. Biol. Conserv. 52, 221-227.

Nugues M.M., Roberts C.M., 2003, Partial mortality in massive reef corals as an indicator of sediment stress on coral reefs. Mar. Pollut. Bull. 46, 314-323.

Nyström M., Folke C., Moberg F., 2000, Coral reef disturbance and resilience in a human-dominated environment. Trends Ecol. Evol. 413-417.

Nyström M., Folke C., 2001, Spatial resilience of coral reefs. Ecosystems 4, 406-417.
Obura D.O., 2005, Resilience and climate change: lessons from coral reefs and bleaching in the Western Indian Ocean. Estuar. Coast. Shelf Sci. 63, 353-372.

O’Neill R.V., Johnson A.R., King A.W., 1989, A hierarchical framework for the analysis of scale. Landscape Ecol. 3, 193-205.

O'Neill R.V., 2001, Is it time to bury the ecosystem concept? (with full military honors, of course!). Ecology 82, 3275-3284.

Öhman M.C., Rajasuriya A., Svensson S. 1998, The use of butterflyfishes (Chaetodontidae) as bio-indicators of habitat structure and human disturbance. Ambio 27, 708-716.

Palandro D., Andréfouët S., Dustan P., Muller-Karger F.E., 2003, Change detection in coral reef communities using the IKONOS sensor and historic aerial photographs. Int. J. Remote Sensing 24, 873-878.

Pastorok R.A, Bilyard G.R., 1985, Effects of sewage pollution on coral-reef communities. Mar. Ecol. Prog. Ser. 21, 175-189.

Pandofi J., Bradbury R., Sala E., Hughes T., Bjorndal K., Cooke R., McArdle D., McClenahan L., Newman M., Paredes G., Warner R., Jackson J., 2003, Global trajectories of long-term decline of coral reef ecosystems. Science 301, 955-958.

Pauly D.G., Silvestre G., Smith I.R., 1989, On development fisheries and dynamite: a brief review of tropical fisheries management. Nat. Res. Model. 3, 307-329.

Peyrot-Claussade M., Le Campion-Alsumard T., Harmelin-Vivien M., Romano JC., Chazotte V., Pari N., Le Campion J., 1995, La bioérosion dans le cycle des carbonates: essai de quantification des processus en Polynésie française. Bull. Soc. Géol. France 166, 85-94.

Pickett S.T.A., White P.S., 1985, Patch dynamics: a synthesis. In: Pickett, S.T.A., White, P.S. (Eds.), The ecology of natural disturbance and patch dynamics. Academic Press, New York, pp. 371-384.

Pickett S.T.A., Kolasa J., Armesto J.J., Collins S.L., 1989, The ecological concept of disturbance and its expression at various hierarchical levels. Oikos 54, 129-136.

Polunin N.V.C., Halim M.K., Kvalvagnaes K., 1983, Bali Barat: an Indonesian marine protected area and its resources. Biol. Conserv. 25, 171-191.

Porcher M., 1993, Intertropical coastal and coral reef areas and their development: practical guide, study methodologies, technical recommendations. Ministère de l'Environnement, Paris.

Quinn, J.F., Dunham A.E., 1993, On hypothesis testing in ecology and evolution. Am. Nat. 122, 602-617.

Randall J.E., 1987, Collecting reef fishes for aquaria. In: Salvat B (ed) Human impacts on coral reefs: facts and recommendations. Antenne Museum EPHE, French Polynesia, pp. 29-39.

Rapport D.J., Regier H.A., Hutchinson T.C., 1985, Ecosystem behavior under stress. Am. Nat. 125, 617-640.

Ray C.G., 1988, Ecological diversity in coastal zones and oceans. In: Wilson E.O. (Ed.), Biodiversity, National Academic Press, Washington DC.

Reese E.S., 1981, Predation on corals by fishes of the family Chaetodontidae: implications for conservation and management of coral rreef ecosystems. Bull. Mar. Sci. 31, 594-604.

Reimer A.A., 1975, Effects of crude oil on corals. Mar. Pollut. Bull. 6, 39-43.

Richmond R.H., 1997, Reproduction and recruitment in corals: critical links in the persistence of reefs. Chapman and Hall, New York, pp. 175-197.

Riegl B., Luke K.E., 1998, Ecological parameters of dynamited reefs in the northern Red Sea and their relevance to reef rehabilitation. Mar. Pollut. Bull. 37, 488-498. 
Riegl B., Velmirov B., 1991, How many damaged corals in Red Sea reef systems? A quantitative survey. Hydrobiologia 216-217, 249-256.

Rinkevitch B., 1995, Restoration strategy for coral reefs damaged by recreational activities: the use of sexual and asexual recruits. Restoration Ecol. 3, 241-251.

Rinkevitch B., Loya Y., 1989, Reproduction in regenerating colonies of the coral Stylophora pistillata. In: Spanier E., Steinberger Y., Luria M. (Eds.), Environmental quality and ecosystem stability. ISEQES, Jerusalem, pp. 257-265.

Risk M., 1972, Fish diversity on a coral reef in the Virgin Islands. Atoll Res. Bull. 153, 1-16.

Roberts C.M., Ormond R.F., 1987, Habitat complexity and coral reef diversity and abundance on Red Sea fringing reefs. Mar. Ecol. Prog. Ser. 41, 1-8.

Rogers S., Gilnack M., Fitz C., 1983, Monitoring of coral reefs with linear transects: a case storm damage. J. Exp. Mar. Biol. Ecol. 66, 285-300.

Rubec P.J., 1988, The need for conservation and management of Philippine coral reefs. Environ. Biol. 23, 141-154.

Saila S.B., Kocic V.L., Mac Manus J.W., 1993, Modelling the effects of destructive fishing practices on tropical coral reefs. Mar. Ecol. Prog. Ser. 94, 51-60.

Salvat B., 1987, Dredging in coral reefs. In: Salvat B. (Ed), Human impacts on coral reefs: facts and recommendations. Antenne Museum EPHE, French Polynesia, pp. 166-184.

Salvat B., Vergonzanne G., Galzin R., Richard G., Chevalier J.P., Ricard M., Renaud-Mornant J., 1979, Conséquences écologiques des activités d'une zone d'extraction de sable corallien dans le lagon de Moorea (île de la Société, Polynésie Française). Cah. Indo-Pacif. 1, 83-126.

Salvat B., Chancerelle Y., Schrimm M., Morancy R., Porcher M., Aubanel A., 2002, Restauration d'une zone corallienne dégradée et implantation d'un jardin corallien à Bora Bora, Polynésie Française. Rev. Ecol. 9, 81-96.

Sano M., Shimuzu, M. Nose, Y., 1984, Changes in structure of coral reef fish communities by destruction of hermatypic corals: observational and experimental views. Pac. Sci. 38, 51-79.

Shepherd A.R., Warwick R.M., Clarke, R.D., Brown, B.E., 1992, An analysis of fish community responses to coral mining in the Maldives. Environ. Biol. Fish 33, 367-380.

Smith S.V., 1985, Coral reef calcification. In: Barnes D.J. (Ed.), Perspectives on coral reefs. Brian Clouston, A.C.T., Australia, pp. 240-247.

Stejskal I.V., 2000, Obtaining approvals for oil and gas projects in shallow water marine areas in western Australia using an environmental risk assessment framework. Spill Sci. Tech. Bull. 6, 69-76.

Thomason J., Roberts C.M., 1992, What is a healthy reef? Reef Encounter 11, 8-9.

Tilmant J.T., 1987, Impacts of recreational activities on coral reefs. In: Salvat B. (Ed.), Human impacts on coral reefs: facts and recommendations. Antenne Museum EPHE, French Polynesia, pp. 195-214.
Tratalos J.A., Austin T.J., 2001, Impacts of recreational SCUBA diving on coral communities of the Caribbean island of Grand Cayman. Biol. Conserv. 102, 67-75.

Underwood A.J., Peterson C.H., 1988, Towards an ecological framework for investigating pollution. Mar. Ecol. Prog. Ser. 46, 227-234.

Van Veghel M.L., Bak R.P., 1994, Reproductive characteristics of the polymorphic Caribbean reef building coral Monastrea annularis. III. Reproduction in damaged and regenerating colonies. Mar. Ecol. Prog. Ser. 109, 229-233.

Veron J.E., 1986, Corals of Australia and the Indo-Pacific. Angus Robertson Publishers, Australia.

Veron J.E., 2000, Corals of the world. Australian Inst Mar Sci, Townsville, Australia.

Ward S., Harrison P., 2000, Changes in gametogenesis and fecundity of acroporid corals that were exposed to elevated nitrogen and phosphorus during the ENCORE experiment. J. Exp. Mar. Biol. Ecol. 246, 179-221.

Wells S.M., Alcala A.C., 1987, Collecting of corals and shells. In: Salvat, B. (Ed.), Human impacts on coral reefs: facts and recommendations. Antenne Museum EPHE, French Polynesia, pp. 13-27.

White A.T., 1987, Effects of construction activity on coral reef and lagoon systems. In: Salvat B. (Ed.), Human impacts on coral reefs: facts and recommendations. Antenne Museum EPHE, French Polynesia, pp. 185-193.

White T.J., Fouda M.M, Rajasuriya A., 1997, Status of reefs in south Asia, Indian Ocean and Middle East seas (Red Sea and Persian Gulf). Proc. 8th Int. Coral Reef Symp. 1, 301-306.

Williams D.M. 1986, Temporal variation in the structure of reef slope fish communities (central Great Barrier Reef): Short-term effects of Acanthaster planci infestation. Mar. Ecol. Prog. Ser. 28, 157-164.

Williams I.D., Polunin N.V.C., 2000, Differences between protected and unprotected Caribbean reefs in attributes preferred by dive tourists. Environ. Conserv. 27, 382-391.

Wolanski E., Pickard G.L., Ripp D.L., 1984, River plumes, coral reefs and mixing in the Gulf of Papua and the northern Great Barrier Reef. Estuar. Coast. Shelf Sci. 18, 291-314.

Woodland D.J., Hooper J.N.A., 1977, The effect of trampling on coral reefs. Biol. Conserv. 11, 1-4.

Yamano H., Tamura M., Kunii Y., Hidaka M., 2003, Spectral reflectance as a potential tool for detecting stressed corals. Galaxea $5,1-10$.

Zakai D., Levy O., Chadwick-Furman N.E., 2000, Experimental fragmentation reduces sexual reproductive output by reef-building coral Pocillopora damicornis. Coral Reefs 19, 185-188.

Zakai D., Chadwick-Furman N.E., 2002, Impacts of intensive recreational diving on reef corals at Eilat, northern Red Sea. Biol. Conserv. 105, 179-187. 